Vol 5 No 1 February 2020

E-ISSN: 2528-410X

ORIGINAL ARTICLE

\title{
Correlation of Nutritional Status with the Incidence of Acute Diarrhea in One to Three Years Children at Amplas Health Center in 2015
}

\author{
Ashry Ramadhana Ginting ${ }^{1}$, Amelia Eka Damayanty ${ }^{2}$ \\ ${ }^{\mathbf{1}}$ Faculty of Medicine University of Muhammadiyah North Sumatera, Medan, Indonesia \\ ${ }^{2}$ Department of Nutrition Health Sciences, Faculty of Medicine University of Muhammadiyah North Sumatera, \\ Medan, Indonesia
}

Corresponding E-mail: ameliaekadamayanty@gmail.com

\begin{abstract}
Nutritional status is a body condition as a result of food consumption and infection status. Nutritional status can be a risk factor of diarrhea. The aim is to determine the correlation of nutritional status with the occurrence of acute diarrhea in children beetween one to three years old at Puskesmas Amplas in 2015. This research is an analytic method of cross sectional and analysis of Chi Square. Using a secondary data from medical records of Puskesmas Amplas. All of bad-nourished respondence often suffering an acute diarrhea within one month. A wellnourished respondence who often suffer from acute diarrhea is $16,7 \%$, and all of obese respondence often suffering an acute diarrhea. There is a correlation between the nutritional status with the occurrence of acute diarrhea with $\mathrm{p}$ value is $0,000(\mathrm{p}<0,05)$ in this research.
\end{abstract}

Keywords: nutritional status, children, acute diarrhea

\section{INTRODUCTION}

Nutritional status is the state of the body as a result of food consumption and use of nutrients. Good nutritional status or optimal nutritional status occurs when the body gets enough nutrients that are used efficiently, so as to enable physical growth, brain development, work ability and general health at the highest level possible. Poor nutritional status occurs when the body lacks one or more essential nutrients. ${ }^{1}$ If the consumption of food nutrition in a person is not balanced with the needs of the body there will be errors due to nutrition (malnutrition). This malnutrition includes excess nutrition / nutrition called overnutrition and undernutrition). ${ }^{2}$

Malnutrition is still a problem in several countries in the world. Malnutrition is the cause of $56 \%$ of deaths in 11 million children worldwide. ${ }^{3}$ Based on the 2013 Riskesdas the prevalence of malnutrition status in children under five in North Sumatra Province ranks second after Aceh with a percentage of $22.4 \%$, greater than the national figure of $19.6 \% .^{4}$ The prevalence of malnutrition status of children under five in Medan in 2013 was $4.2 \%$ and malnutrition was $15.1 \% .^{5}$ Nutritional status is influenced by several factors such as diarrhea infection. ${ }^{2}$ 
E-ISSN: 2528-410X

Diarrheal disease is recognized by the presence of changes in the shape and consistency of feces and increased frequency of bowel movements more than three times or more in 24 hours. Can be accompanied by vomiting or bloody or slimy stool. Diarrhea is often found in toddlers, especially in the first three years of life, where a child can experience one to three episodes of severe diarrhea. $^{6}$

Based on the length of time the diarrhea consists of acute diarrhea, chronic diarrhea, and persistent diarrhea. Acute diarrhea is diarrhea that lasts less than 14 days and occurs at any time, with soft or liquid excretion with or without mucus and blood. Chronic diarrhea is diarrhea that lasts a long time, disappears or arises from noninfectious causes, such as metabolic disorders that last more than 30 days. Persistent diarrhea is diarrhea that lasts 15-30 days, is a continuation of acute diarrhea or transition from acute and chronic diarrhea.. ${ }^{7}$

Nutritional status can affect the immune system. Therefore, researchers want to know the correlation of nutritional status with the incidence of acute diarrhea in children aged one to three years at Amplas Health Center in 2015.

\section{METHODS}

This research is analytic descriptive with cross sectional method and analysis with Chi Square. This study uses secondary data from the Amplas Health Center. The sample selection is done by the Probability Sampling method. In this study the variables to be measured are acute diarrhea infection and nutritional status. The nutritional status of children is determined using the CDCNCHS 2000 curve based on the eid index that meets the inclusion and exclusion criteria.
Inclusion criteria were all children aged one to three years who suffered acute diarrhea based on secondary data from the nutritional status examination results from Amplas Health Center. Exclusion criteria are children aged one to three years who have chronic diarrhea.

\section{RESULTS}

Based on secondary data obtained, the number of samples that were tested for acute diarrhea was 50 people.

Based on the results of the study obtained the frequency of samples that are male - totaled 24 people $(48 \%)$ and female sex totaled 26 people (52\%) seen in table 1 .

Table 1. Distribution of Samples by Gender

\begin{tabular}{lcc}
\hline Gender & Frequency & Percentage (\%) \\
\hline Male & 24 & 48 \\
Female & 26 & 52 \\
\hline Total & 50 & 100
\end{tabular}

Based on table 1 it can be seen that the number of samples of female sex is greater than that of male sex with a percentage of $52 \%$.

Based on the results of research on children aged one to three years at the Amplas Health Center, the age of 12-24 months totaling 24 people (48\%), and 25-36 months totaling 26 people $(52 \%)$ which can be seen in table 2

Table 2. Distribution of Samples by Age

\begin{tabular}{lcc}
\hline Age & Frequency & Percentage (\%) \\
\hline $12-24$ mo & 24 & 48 \\
$25-36$ mo & 26 & 52 \\
\hline Total & 50 & 100 \\
\hline
\end{tabular}

Based on table 2, the largest sample is age 24-56 months with a percentage of $52 \%$. Description of nutritional status in children aged one to three years at Amplas Health 
E-ISSN: 2528-410X

Center in 2015 based on the study found that children with poor nutritional status are as many as two children (4\%), nutritional status as many as three children (6\%), good nutritional status as many as 42 children (84\%), and over three children (6\%) nutritional status can be seen in table 3

Table 3. Nutritional Status of The Sample

\begin{tabular}{llcc}
\hline $\begin{array}{c}\text { Nutritional } \\
\text { status interval } \\
\text { (BMI/Age) }\end{array}$ & Criteria & Amount & $\%$ \\
\hline$<-3$ SD & $\begin{array}{l}\text { Severly } \\
\text { wasted }\end{array}$ & 2 & 4 \\
$<-2$ to -3 SD & Wasted & 3 & 6 \\
-2 to +2 SD & Normal & 42 & 84 \\
$>2$ SD & $\begin{array}{l}\text { Over- } \\
\text { weight }\end{array}$ & 3 & 6 \\
& & 50 & 100 \\
\hline Total & & & \\
\hline
\end{tabular}

${ }^{*}$ based on the WHO-NCHS curve

Based on table 3 , the most nutritional status in the sample is good nutritional status by $84 \%$

Based on the results of the study, it was found that the frequency of acute diarrhea in the last month as many as 35 children $(70 \%)$ rarely experience it and as many as 15 children $(30 \%)$ often experience it, which can be seen in table 4 .

Table 4. Description of The Incidence of Acute Diarrhea

\begin{tabular}{cccc}
\hline $\begin{array}{c}\text { Diarrhea } \\
\text { incidence } \\
\text { (time/month) }\end{array}$ & Criteria & Frequency & $\%$ \\
\hline $1-2$ & Rare & 35 & 70 \\
$>2$ & Often & 15 & 30 \\
\hline Total & & 50 & 100 \\
\hline
\end{tabular}

Based on the results of the study, obtained results with severly wasted as many as five people (13.9\%), wasted as many as 14 people (38.9\%), normal as many as 15 people $(41.7 \%)$, overweight as many as two people $(5.6 \%)$. While severe malnutrition and obesity were not found.
Table 5. Correlation of Nutritional Status with The Incidence of Acute Diarrhea

\begin{tabular}{ccccccc}
\hline \multirow{2}{*}{ NS } & \multicolumn{7}{c}{ IAD } \\
\cline { 2 - 7 } & \multicolumn{2}{c}{$\mathbf{R}$} & \multicolumn{2}{c}{$\mathbf{0}$} & \multicolumn{2}{c}{ Jumlah } \\
\cline { 2 - 7 } & $\mathbf{n}$ & $\%$ & $\mathbf{n}$ & $\%$ & $\mathbf{n}$ & $\%$ \\
\hline SW & 0 & 0 & 2 & 4 & 2 & 4 \\
W & 0 & 0 & 3 & 6 & 3 & 6 \\
N & 35 & 70 & 7 & 14 & 42 & 84 \\
0 & 0 & 0 & 3 & 6 & 3 & 6 \\
\hline Total & 35 & 70 & 15 & 30 & 50 & 100 \\
\hline
\end{tabular}

Notes:

NS = Nutritional status; IAD = Incidence of acute diarrhea; $\mathbf{R}=$ Rare; $\mathbf{O}=$ Often; $\mathbf{S W}=$ Severly wasted; $\mathbf{W}=$ Wasted; $\mathbf{N}=$ Normal; $0=$ Overweight

Table 5 shows that all respondents with severely wasted and wasted tend to be more often experience acute diarrhea. However, respondents with good nutrition who often experience acute diarrhea are only 7 out of 42 people. Chi Square test results showed $\mathrm{p}$ 0.001 so that it can be concluded that there is a correlation between nutritional status with the incidence of acute diarrhea.

\section{DISCUSSIONS}

In this study, the sample with a greater number of female sex than men with a percentage of $52 \%$ female and $48 \%$ male. The same thing was also found in Hilyah's research with the characteristics of $\mathrm{m}$ ore female samples, namely $54.2 \%$ compared to men $45.8 \%{ }^{8}$

Most samples in this study were samples age 25-36 months 52\%, other samples aged 12-24 months 24\%. This is different from the sample in the Hilyah study with the most samples at the age of 12-24 months totaling 46 toddlers $(47.9 \%){ }^{8}$

Based on the results of research on children aged one to three years at Amplas Health Center which is infected with acute diarrhea and nutritional status examination results obtained that $84 \%$ of children aged one to three years who have acute diarrhea at 
Amplas Health Center have good or normal nutritional status with frequent frequency as much as $14 \%$. The same results found in previous studies on the correlation of nutritional status with the frequency of diarrhea occurrences in toddlers showed that the results of good nutritional status were 79 children $(82.3 \%)$ and other studies regarding the correlation between diarrhea events and the nutritional status of children under five in Bakonang Village, Mojolaban District the results obtained that of 90 toddlers as many as 73 toddlers $(81.1 \%)$ have good nutritional status. $^{8,9}$

From the results of descriptive research on the incidence of acute diarrhea in children aged one to three years showed that the frequency of acute diarrhea in the last month is rarely as many as 35 children (70\%) with good nutritional status and often as many as 15 children $(30 \%)$ in samples with poor nutritional status.

In this study, the analysis used was the chi square test. The significance value indicates 0.001 . Therefore $\mathrm{p}<0.05$, it can be concluded that there is a correlation between nutritional status and the incidence of acute diarrhea. This is different from previous research. $^{8,9}$

The incidence of diarrhea is very closely related to a person's nutritional status. Good nutritional status in individuals has sufficient ability to defend themselves against infectious diseases. Meanwhile, if in a state with a nutritional status that is not optimal, the immune reaction will decrease so that self-defense against infection also decreases. Therefore, any form of nutritional disorders with even mild symptoms of deficiency is an early sign of immune disruption to infectious diseases. ${ }^{10}$

In children with malnutrition diarrhea attacks occur more frequently and for longer.
The worse the child's nutritional status, the more often and more severe the diarrhea he suffers. It is suspected that intestinal mucosa which is in a nutritionally deficient state is especially sensitive to infections. ${ }^{11}$

Children aged two to five years are active consumers who are often exposed to food outside the home or contaminated food. At this age, children prefer to eat snacks with friends outside the home without paying attention to the processing and serving of foods that are likely to be less hygienic, so susceptible to food contamination by bacteria that can cause children to suffer from diarrhea. $^{12}$ Diarrhea can be caused by food intoxication, bacterial contaminated food or due to allergies or intolerance and malabsorption of certain nutrients such as carbohydrates, fats, proteins, vitamins and minerals. $^{7}$

Epidemiological data show that more nutrition is also associated with symptoms of complaints of gastrointestinal disorders. Glucose absorption in patients with less obese nutritional status can increase the incidence of osmotic diarrhea. ${ }^{13}$ Of the five studies that analyzed the correlation of obesity with chronic gastrointestinal symptoms, four studies found positi ve symptoms of diarrhea and one study showed a negative correlation. ${ }^{13}$

\section{CONCLUSIONS}

There is a correlation between nutritional status and the incidence of acute diarrhea in children aged one to three years.

\section{ACKNOWLEDGEMENT}

Gratitudes are addressed to the Dean of FK UMSU and the Head of the Amplas Health Center who facilitated this research. 


\section{REFERENCES}

1. Almatsier S. Prinsip Dasar Ilmu Gizi.Jakarta: Gramedia Pustaka Utama. 2010.

2. Notoatmodjo S. Kesehatan Mayarakat. Edisi Revisi. Jakarta:Rineka Cipta.2011

3. Repositioning Nutrition as Central to Development: A Strategy for LargeScale Action. USA: World Bank.2006

4. Kementerian Kesehatan RI. Situasi dan Analisis Gizi. Jakarta:Pusat Data dan Informasi 2015

5. Profil Kesehatan Sumatera Utara 2013

6. Simatupang M. Analisis Faktor-faktor yang Berhubungan dengan Kejadian Diare pada Balita di Kota Sibolga Tahun 2008. Medan.2009

7. Asnil P. Gastroenteritis Akut dalam; Suharyono, Halimun. Gastrologi Anak Praktis. Jakarta. 2003.

8. Hilyah, M. Hubungan Status Gizi Dengan Frekuensi Kejadian Diare Pada
Balita Di Kelurahan Pisangan Bulan Agustus 2010. UIN Syarif Hidayatullah. Jakarta.2011

9. Amri, M. Hubungan Antara Kejadian Diare dengan Status Gizi Anak Balita Di

Kelurahan Bekonang Kecamatan Majolaban Kabupaten Sukoharjo. Universitas Muhammadiyah Surakarta. Surakarta. 2014.

10. Supariasa IDN. Penilaian Status Gizi. Jakarta. EGC.2002.

11. Suharyono. Gastrologi Anak Praktis Cetakan Keempat. Jakarta.2003.

12. Palupi, A., Hadi, H., \& Soenarto. Status Gizi dan Hubungannya dengan Kejadian Diare pada Anak. Diare Akut di Ruang Inap RSUP Dr. Sardjito. Yogyakarta.2003.

13. Ho, W\& Spiegel, B. The Correlation Between Obesity and Functional Gastrointestinal and Hepatology.2012. 